\title{
The Impact of Credit on Income Inequality in Vietnam*
}

\author{
Quoc Hoi LE ${ }^{1}$, Bich Ngoc NGUYEN ${ }^{2}$
}

Received: February 27, 2020 Revised: March 15, 2020 Accepted: April 03, 2020

\begin{abstract}
This paper examines the impacts of credit on income inequality in Vietnam. Though it is one of the most common measures of financial development, there is a dearth of research in this area. Unlike previous studies, the paper disaggregates the impact of each type of credit on income inequality, looking at the Gini coefficient. We employ the Generalized Method of Moment (GMM) to solve the endogenous problem. The primary data set contains a panel of 60 Provincial observations, from data collected from the General Statistics Office of Vietnam from 2002 to 2016. The empirical findings show that, while commercial credit increases income inequality, policy credit contributes to reducing income inequality in Vietnam. The results also confirm the important roles of education, institutional quality and foreign direct investment in fighting against income inequality in Vietnam. However, the paper does not provide adequate evidence to support the inverted U-shaped relationship between credit and income inequality. Based on the findings, we argue that the government should direct flows of credit to real economic activities rather than speculative investment; more bank credit should be allocated to rural areas and agriculture; and favorable credit programs should be designed to promote education, especially of those living in rural areas.
\end{abstract}

Keywords : Credit, Income Inequality, Vietnam.

JEL Classification Code: Q4, I3, O11.

\section{Introduction}

The impact of financial development in general and credit in particular on income inequality has been theatrically and empirically studied in the world. The studies such as Galor and Zeira (1993), Benerjee and Newman (1993), and Greenwood and Jovanovic (1990) basically explain how credit affects income inequality. However, theoretical studies have not entirely agreed about the direction of the relationship between credit and income inequality. Thus, many empirical studies have been effectuated to examine

\footnotetext{
*Acknowledgement: This research is funded by the National Economics University.

${ }^{1}$ First Author and Corresponding Author. Associate Professor, Faculty of Economics, The National Economics University, Vietnam [Postal Address: 207 Giai Phong Road, Dong Tam Ward, Hai Ba Trung District, Hanoi, 116000, Vietnam], Email: hoilq@neu.edu.vn ${ }^{2}$ Lecturer, School of Trade and International Economics, National Economics University. Email: ngocnb@neu.edu.vn
}

(c) Copyright: The Author(s)

This is an Open Access article distributed under the terms of the Creative Commons Attribution Non-Commercial License (http://Creativecommons.org/licenses/by-nc/4.0/) which permits unrestricted noncommercial use, distribution, and reproduction in any medium, provided the original work is properly cited. impacts of credit on income inequality in many countries scope as well as in a specific country. Nationally, studies at different levels with different aspects show that income inequality is related to credit, however, the mechanisms and degrees of impact differ from country to country and are subject to each country's institutional and socio-economic background.

Vietnam has made a number of remarkable achievements in social and economic development since more than 30 years of economic reform. Economic growth has brought Vietnam from the country with the rate of more than $58 \%$ poor population in 1993 to about 5\% in 2018 (Pham \& Riedel, 2019). Credit is considered as a factor to contribute to this great achievement. However, income inequality in society tends to increase in the line with the achievement of rapid economic growth and sharply poverty reduction in Vietnam. Gini coefficient, a common measure of income inequality, increases from 0.34 in 1993 to 0.42 in 2018 (GSO, 2019). Increasing income inequality is not beneficial to the economic growth and engenders a high cost of overcoming its social consequences in the long term, especially when the awareness about this situation increases among social groups. Increasing income inequality is also one of the factors affecting Vietnam's escape from the middle-income trap (Ohno, 2010). 
So far, there have been several studies examining the impact of financial development on income inequality in Vietnam, and different empirical findings are coming out, depending on the representative variable of financial development (Le \& Chu, 2012). However, there is no study on the impact of credit, one of the most common measures of financial development, on income inequality. In addition, the studies also have not separated the impact of each type of credit on income inequality. Therefore, this study will address these gaps.

The paper is organised as follows. Section 2 provides theoretical framework and literature review. An overall of credit market development and income inequality in Vietnam is presented in Section 3. Section 4 describes model specification, data and methodology. The empirical results and discussion are presented in Section 5. And section 6 offers conclusions and policy implications.

\section{Literature Review}

There have been three main strands of theory about the credit-inequality nexus until today. Out of the three, the one developed by Greenwood and Jovanovic (1990), also known as non-linear or inverted U-shaped hypothesis, states that credit leads to higher inequality in early stage of economic development, but the income gap may decreases as the credit market has been grown to mature. The other one proposed by Galor and Zeira (1993) and Banerjee and Newman (1993) predicts that credit has the effect of reducing income inequality, called the linear hypothesis. In addition, Aghion and Bolton (1997) provides a trickle-down theory, which implies that when capital accumulation is high enough, a governmental policy may still make income distribution more equal if it redistributes more wealth of the richer lenders to poorer borrowers, which could be done through credit allocation mechanism.

Based on those theoretical frameworks, a variety of empirical studies have been done in various scopes of geography, aspects, time and methods. In a group of studies on a global scale, Clarke, $\mathrm{Xu}$, and Zou (2003) studying 91 countries from 1960 to 1995 finds a high correlation between low levels of income inequality and credit. Beck, DemirgũcKunt, and Levine (2007) performs a quantitative analysis on a sample of 52 countries from 1960-1999, showing that credit can reduce income inequality. Kappel (2010) analyses data from 78 countries including developed and developing countries from the 1960s to 2006, showing the same conclusion as in Africa. Previously, when comparing inequality in more than 160 countries, Honohan (2007) certifies that in countries where households have a better access to credit, Gini coefficient in these countries is lower. Asad (2012) studies a sample of 107 countries in the period 1960-2010 and uses the Generalized Method of Moment
(GMM) has found empirical evidence showing that credit has a positive impact on the income distribution, depending on human capital level of each country. Recently, Dhrifi (2013) studies for the period 1990-2010 of 22 low-income countries, 37 middle-income countries and 30 high-income countries proving that credit only has the effect of reducing inequality in high-income countries, while has an impact on increasing inequality in low-income and middle-income countries.

In the group of studies on a national level, Jalil and Feridun (2011) for China from 1978 to 2007 conclude that credit helps to reduce income inequality. In India, Ang (2010) provides a quantitative analysis on a time series data during 1951-2004 finds that credit expansion for the private sector and bank consistence may narrow income inequality. In Pakistan, Shahbaz and Islam (2011) analyses national data from 1971 to 2005, showing that credit leads to more equal distribution and less financial instability. In Iran, Baligh and Pirace (2013) using national data for the period of 1973-2010 confirming that the more developed credit is, the less income gap is. This study supports the linear hypothesis suggested by Galor and Zeira (1993), but no evidence of nonlinear relation has been found.

In addition to studies proving the role of credit in improving income distribution in a way that is more beneficial to the poor, there are also studies showing the opposite outcomes. Zhang and Chen (2015) observe that credit enlarges urbanrural income gap in the early stage of economic development in China. In the Philippines, Cruz and Imperial (2014) use data in the period 1961-2000 which certifies that credit increases inequality. This is the result of the fact that the financial development in the Philippines is not accompanied by improved competitiveness, operational efficiency as well as greater availability of provided financial products, which originates from a monopoly banking system. In another Asian country, Malaysia, Law and Tan (2009) find no evidence to conclude that credit can reduce the rich-poor gap when analyzing national data from 1980 to 2000 . Re-examining this correlation in the context of better government institutional quality, Law, Tan, and Azman-Saini (2014) conclude that credit only reduces the income gap after the institutional quality has reached a certain threshold. Mago (2014) and Nguyen and Lien (2019) argue that access to finance by rural farmers enables them to acquire credit and accumulate savings. This has an impact on improving the disposable income for consumption and investment hence reducing income inequality.

In Vietnam, studies about the financial impact on income inequality have recently attracted interest. Nguyen, Bigman, Berg, and $\mathrm{Vu}$ (2007) and $\mathrm{Ha}$ (2019) find that access to micro-credit provided by Vietnam Bank for Social Policies can not only alleviate poverty, but reduce slightly income inequality as well. Research by Le and Chu (2012) is the first study using the array data estimation by province level, showing that financial development can reduce income 
inequality. Similar conclusion is found in Le and Chu (2013) when analyzing similar data with solid regression methods. However, in both studies, the variables representing financial development are built on data of financial firms' numbers, assets, and revenue, while the Vietnamese financial market is mainly based on its banking system.

Therefore, the indicators representing the financial development do not entirely reflect all dimensions of credit development. In addition, estimation techniques have not completely overcome possible defects in the quantitative model, which leads to the conclusions that may not be completely solid. The use of a more diverse data with longer duration may determine the impact of credit on income inequality better.

\section{Overview of Credit Market and Income Inequality in Vietnam}

\subsection{Credit Market Development}

During the period 2000-2010, credit grew rapidly at an average rate of $32.2 \%$ year-on-year, peaking at $54 \%$ in 2007 (see Figure 1). Successively high credit growth for many years contributed greatly to rising financial depth of credit market. According to the Asian Development Bank (2015), outstanding domestic credit claims by private sector (as percentage of GDP) in 1999 is only equivalent to $22 \%$, increases rapidly at $115 \%$ in 2010 , then drops to $100 \%$ in 2014. However, from 2011 to 2018, the average rate of credit growth remained only about $13.3 \%$ year-on-year.

It can be seen that, for a long time, Vietnam has taken credit expansion as a factor to promote economic growth. However, a large proportion of credit has not been transformed into real, productive activities, such as agriculture and manufacturing, but is transferred to speculative activities such as construction and real estate. Statistical data of the State Bank of Vietnam (2019) shows that credit for agriculture and manufacturing industry in the period of $2015-1018$ accounted for $10 \%$ and $25 \%$ of the total credit; about $55-59 \%$ of communes across the country have difficulty in accessing to the formal credit market; $70 \%$ of small and medium enterprises have challenges or cannot reach a credit from an official financial institution. These facts explain why GDP growth is not strongly correlated with credit growth as shown in Figure 1.

\subsection{Income Inequality in Vietnam}

Figure 2 shows that Vietnam's income inequality in the period of 2006-2018 is unstable and fluctuates. The Gini coefficient from 0.424 in 2006 increases to 0.434 in 2008 , then gradually decreases to 0.424 in 2012 , increases again and reaches the highest value during this period of 0.436 in 2016, and drops to 0.422 in 2018. Although the fluctuation degree of the Gini coefficient is not much $(0.422$ to 0.436 ), it also shows that the income of employees changes over the years. According to Cornia and Court (2001), Gini coefficient in the range of $0.30-0.45$ shows the safe and effective range of income inequality. Based on the actual Gini data, it can be affirmed that Vietnam's income inequality is still in a safe area. With this threshold, the level of income inequality in Vietnam is acceptable in trade-off for high economic growth.

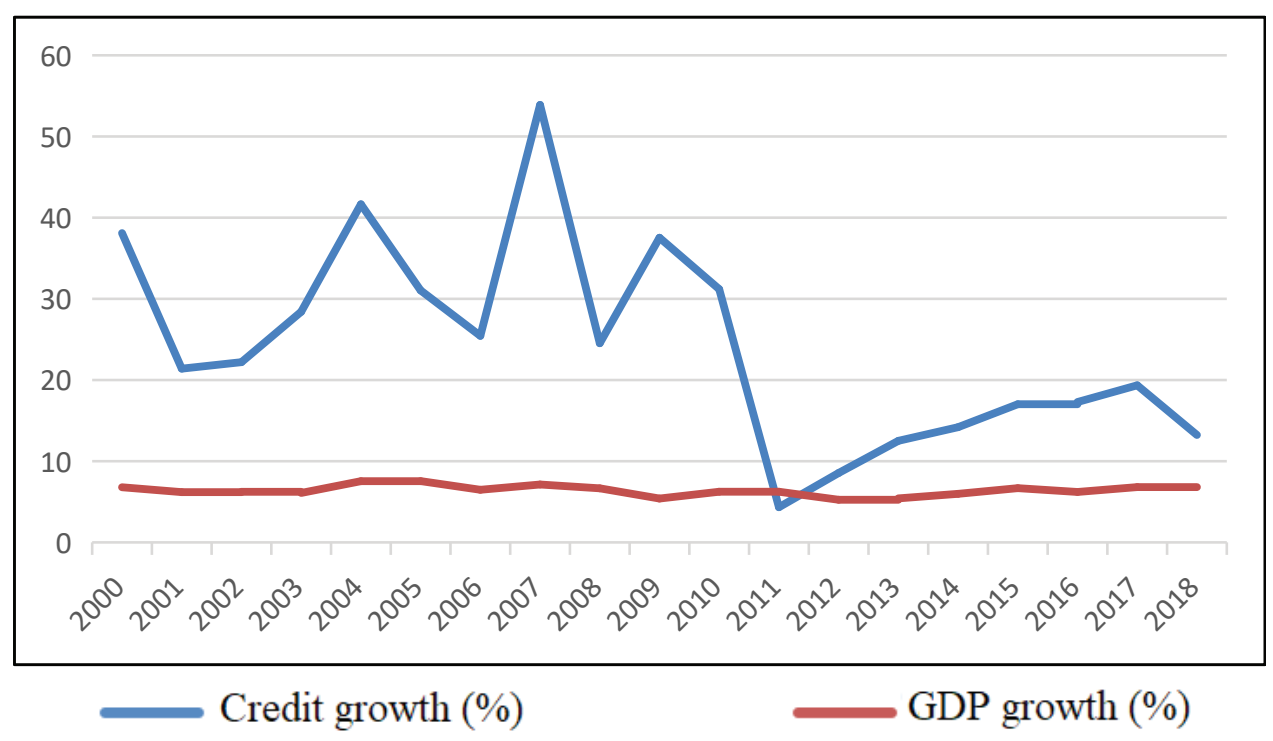

Figure 1: Credit growth and GDP growth 2000-2018

Source: State Bank of Vietnam 


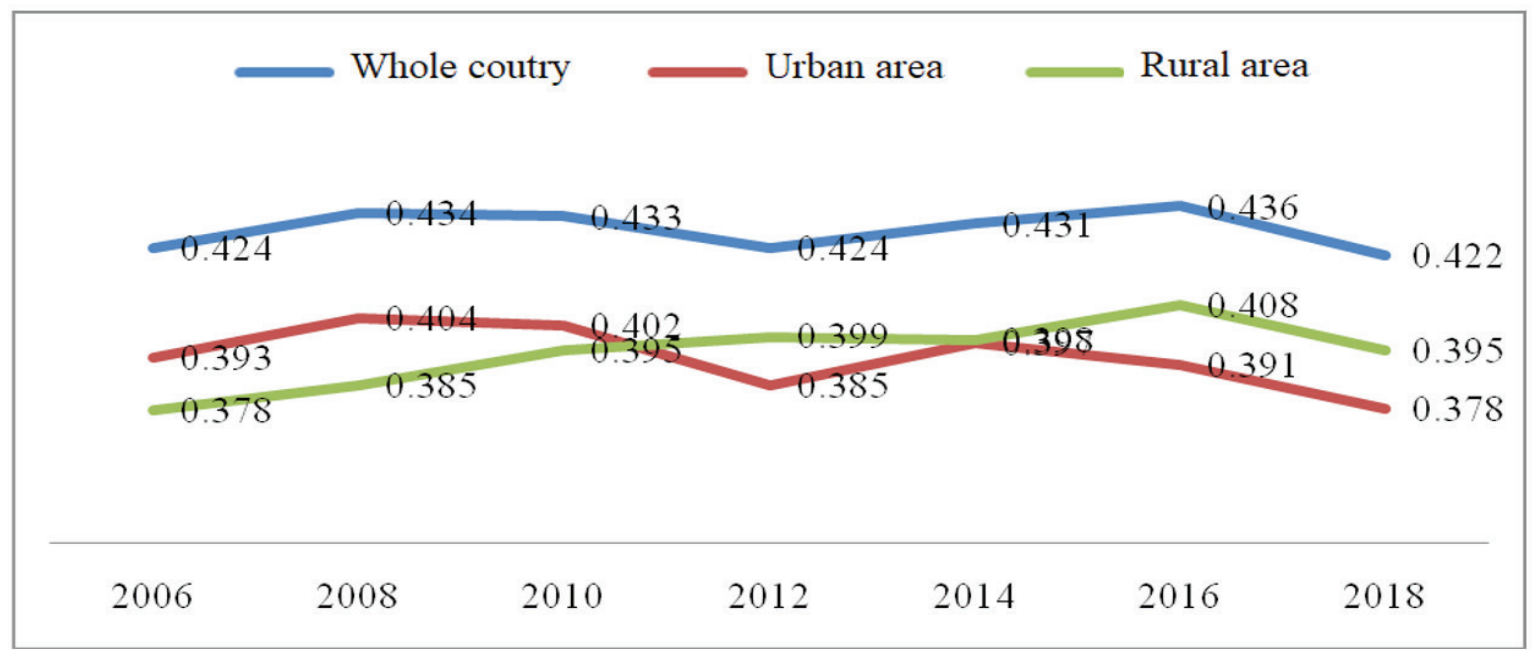

Figure 2: Income inequality (Gini coefficient) in Vietnam from 2006 to 2018

Source: General Statistics Office of Vietnam

However, the level of inequality in Vietnam may be higher than what is shown by the above Gini coefficient, because the Gini coefficient does not take into account the inequality factor caused by the differences in assets, opportunities to access resources, health care, education and corruption. This may be partly reflected by the income gap between the richest quintile (group 5) and the poorest quintile (group 1) in Table 1.

Table 1: Average monthly income per person by 5 income groups in Vietnam

(2008-2018)

Unit: Thousand dong

\begin{tabular}{|c|c|c|c|c|c|c|c|c|}
\hline Year & Average & Group 1 & Group 2 & Group 3 & Group 4 & Group 5 & (1) & (2) \\
\hline 2008 & 995 & 275 & 477 & 700 & 1067 & 2458 & 2183 & 8.94 \\
\hline 2010 & 1387 & 369 & 669 & 1000 & 1490 & 3410 & 3041 & 9.24 \\
\hline 2012 & 2000 & 512 & 984 & 1500 & 2222 & 4784 & 4272 & 9.34 \\
\hline 2014 & 2637 & 660 & 1314 & 1972 & 2830 & 6413 & 5753 & 9.72 \\
\hline 2016 & 3098 & 771 & 1516 & 2301 & 3356 & 7547 & 6776 & 9.79 \\
\hline 2018 & 3760 & 931 & 1808 & 2774 & 4110 & 9175 & 8244 & 9.86 \\
\hline
\end{tabular}

Source: General Statistics Office of Vietnam

Note: (1) Income gap between group 5 and group 1; (2) Number of income disparities between group 5 and group 1

Table 1 shows that the average monthly income in all five income groups has increased over the years. The average monthly income per person in 2018 is 3.78 times higher than in 2008. In 2008, the income of group 5 is 8.9 times higher compared to group 1, but by 2018, the income of group 5 is 9.86 times higher compared to group 1, which has pushed the income gap increasingly far. This data shows that income inequality over this period tends to increase rapidly. Comparing income in 2018 and 2008 indicates that group 1 is the group with the slowest increase level (3.38 times) compared to the remaining groups, while group 2 increases 3.79 times, group 3 increases at the highest level of 3.96 times and group 4 increases 3.85 times, group 5 increases 3.73 times.

Another measure of inequality, the " $40 \%$ " standard of the World Bank, also reflects income inequality. Specifically, the income proportion of the poorest $40 \%$ of total population and the total population has continuously decreased from approximately $18 \%$ in 2002 to about $15 \%$ in $2010,14.9 \%$ in 2012 and continued to decline to $14.6 \%$ in 2018, which reflects the rise of absolute inequality in Vietnam. It can be easily seen, while the relative inequality level measured by the Gini coefficient is acceptable, that the absolute income gap is strongly concerned, because this demonstrates the 
increasingly rich-poor gap in Vietnamese society. It is also important to clarify that rising inequality does not imply that the rich become richer, and the poor become poorer; but the income growth of the rich group is faster than the income growth of the poor and low-income groups.

\section{Research Methodology}

\subsection{Model Specification}

This study uses an approach from Liang (2006) and Batuo et al. (2010) with the model specification is as follows:

In this equation, Gini is Gini coefficient; taking value from 0 to 1 . CRED is abbreviation for credit, measured by two variables: C.CRED, commercial credit, is computed by taking domestic credit claimed by private sector as percentage of GDP; and P.CRED, policy credit, is computed by taking policy credit as percentage of GDP. X is a set of other control variables including: GDPPC is GDP per capita in real term at comparable 1994 price; EDU is a proxy for educational attainment. In this study, we use number of schooling years of household head. OPEN, a proxy for openness of the economy, is calculated by sum of import and export revenue as percentage of GDP. CPI is abbreviation of consumer price index, which measures inflation. PCI is the provincial competitiveness index, which measures the institutional quality.

Testing if the impact of CRED on Gini would be changed under various contexts of government intervening into redistribution is made through fiscal policy. The rationale for including these variables is GEX variable - government size measured by government expenditure size over GDP. Also, we include FDI (foreign-owned sector investment as percentage of GDP) and to see if the presence of FDI company would help promote some equality. PINV (proxy for private sector investment) and SINV (proxy for state sector investment) are added. Finally, we add squared term of CRED (sqCRED) into the model so as to test the nonlinear relationship suggested by Greenwood and Jovanovic (1990).

\subsection{Data}

Data used in this paper for empirical analysis is collected from the following sources: Gini coefficient is calculated by the author from Vietnam Household Living Standard Survey (VHLSS) from 2002 to 2016. Since 2002, the General Statistics Office of Vietnam (GSO) conducts VHLSS every two years. The survey is designed to cover the whole country to represent the socio-economic changes of the country at national and provincial level. Data of education in the model is also computed from these surveys in corresponding years. Data for generating other variables in the model is collected from GSO, which includes: GDP, import and export revenue, public expenditure, total social investment by ownership, and inflation. Data on institutional quality is collected from Vietnam Chamber of Commerce and Industry. One note is that Vietnam currently has 63 cities/provinces, but there happened some events of splitting and/or merging some provinces during 2002-2016, so in order to have a balanced panel data without reducing observations, we combine data of pair of respectively separated/merged provinces for the whole studying period. Thus, the primary data set contains a panel of 60 provincial observations.

There are no official sources that collect data on credit market size at provincial level, but national level. Fortunately, data about GDP generated by the financial sector in each province/city could be traced in provincial agencies of GSO. Given that, we refer to a method employed by Bittencourt (2010) to construct the value of credit market depth at provincial level in Vietnam as follows:

Where GDPFi,t represents GDP by financial sector of province $\mathrm{i}$ in year $\mathrm{t}$. Summation mark in $\Sigma$ C.CRED implies the sum of grouped provinces, which is already known.

\subsection{Methodology}

To solve endogenous problems, we utilize Generalized Method of Moment (GMM) to analyse the dataset for the case of Vietnam in this study. In practice, Difference GMM (DGMM) could be used to generate empirical results by taking first-difference. Nevertheless, DGMM may still contain limits because taking first order differentiation would make cross-province and within-province long-term information disappear. Furthermore, lagged variables could be weak instrument for its differenced variable. To solve this, we could use an alternative technique, which uses both lagged differenced dependent and independent variables as instruments. To test the phenomenon of auto-correlation, Arellano-Bond is applied with error term in differenced equation. Sargen/Hansen test indicates the overall validity of set of instruments. However, there is no instruction of how much instrument is too many (Roodman, 2006). Moreover, when executing robust regression to correct problem of heteroskedasticity, Hansen test of over-identification could be unreliable. We therefore, suggested by Roodman (2006), apply rule of thumb that number of instruments does not exceed that of observation groups.

\section{Empirical Results}

The estimated results in all columns in Table 2 show that the results are quite similar. The coefficient of variable C.CRED is initially slated to be positive, implying that the increase of commerce credit may push to raise income inequality in Vietnam. Specifically, the coefficient of 
C.CRED falls in the range of 0.0022 to 0.0024 , which could be briefly interpreted that on average, for a province whose credit market depth is one percentage point higher than that of another province, its Gini coefficient would be roughly $0.23 \%$ higher. The estimation results are consistent with the fact that credit market in Vietnam triggers speculative investment. However, the coefficient of variable P.CRED is negative, implying that the increase of policy credit may reduce income inequality in Vietnam. Specifically, a province whose credit market depth is one percentage point higher than that of another province, its Gini coefficient would be average $0.11 \%$ lower. This reflects that policy credit has an impact on helping the poor and vulnerable, thereby contributing to reduce income inequality in Vietnam.

In addition to the findings for targeted variable CRED, our empirical results strongly emphasize the importance of raising the educational level as a tool to alleviate inequality, whereas higher volatile economic environment, manifested CPI, obviously does not favor the poor. The taking on a positive sign, though not statistically significant in all regression, coefficient of real GDP per capita (RGDPPC) implies that economic growth in the country may have an

Table 2: Regression results

\begin{tabular}{|c|c|c|c|c|}
\hline $\begin{array}{l}\text { Explanatory } \\
\text { variables }\end{array}$ & I & II & III & IV \\
\hline C.CRED & $\begin{array}{c}0,0023^{\star * *} \\
(4,14)\end{array}$ & & $\begin{array}{c}0,0022^{\star * *} \\
(4,02)\end{array}$ & $\begin{array}{c}0,0022^{* * *} \\
(4,01)\end{array}$ \\
\hline P.CRED & & $\begin{array}{c}-0,0012^{* * *} \\
(3,88)\end{array}$ & $\begin{array}{c}-0,0011^{* * *} \\
(3,92)\end{array}$ & $\begin{array}{c}-0,0012^{* * *} \\
(3,89)\end{array}$ \\
\hline RGDPPC & $\begin{array}{c}0,0016 \\
(1,17)\end{array}$ & $\begin{array}{c}0,0021^{*} \\
(1,97)\end{array}$ & $\begin{array}{c}0,0019 \\
(1,62)\end{array}$ & $\begin{array}{c}0,0019 \\
(1,72)\end{array}$ \\
\hline EDU & $\begin{array}{c}-0,0334^{* * *} \\
(-3,70)\end{array}$ & $\begin{array}{c}-0,0323^{* * *} \\
(-3,57)\end{array}$ & $\begin{array}{c}-0,0328^{* * *} \\
(-3,60)\end{array}$ & $\begin{array}{c}-0,0325^{* * *} \\
(-3,64)\end{array}$ \\
\hline CPI & $\begin{array}{c}0,0038^{* * *} \\
(3,51)\end{array}$ & $\begin{array}{c}0,0039^{* * *} \\
(3,52)\end{array}$ & $\begin{array}{c}0,0040^{* * *} \\
(3,31)\end{array}$ & $\begin{array}{c}0,0040^{* * *} \\
(3,21)\end{array}$ \\
\hline OPEN & $\begin{array}{c}-0,0001 \\
(-0,68) \\
\end{array}$ & $\begin{array}{c}-0,0001 \\
(-0,57) \\
\end{array}$ & $\begin{array}{c}-0,0001 \\
(-0,66) \\
\end{array}$ & $\begin{array}{c}-0,0001 \\
(-0,67) \\
\end{array}$ \\
\hline GEX & $\begin{array}{c}0,0007 \\
(1,11)\end{array}$ & $\begin{array}{c}0,0007 \\
(1,12)\end{array}$ & $\begin{array}{c}0,0007 \\
(1,13)\end{array}$ & $\begin{array}{c}0,0007 \\
(1,18)\end{array}$ \\
\hline SINV & $\begin{array}{c}0,0003 \\
(0,20)\end{array}$ & $\begin{array}{c}0,0003 \\
(0,21)\end{array}$ & $\begin{array}{c}0,0003 \\
(0,22)\end{array}$ & $\begin{array}{c}0,0003 \\
(0,23)\end{array}$ \\
\hline PINV & $\begin{array}{c}0,0008 \\
(0,27)\end{array}$ & $\begin{array}{c}0,0008 \\
(0,28)\end{array}$ & $\begin{array}{c}0,0008 \\
(0,29)\end{array}$ & $\begin{array}{c}0,0008 \\
(0,27)\end{array}$ \\
\hline FDI & $\begin{array}{c}-0,002^{* * *} \\
(-3,60)\end{array}$ & $\begin{array}{c}-0,002^{* * *} \\
(-3,62)\end{array}$ & $\begin{array}{c}-0,0021^{* * *} \\
(-3,63)\end{array}$ & $\begin{array}{c}-0,0021^{\text {*** }}(-3,65)\end{array}$ \\
\hline $\mathrm{PCl}$ & $\begin{array}{c}-0,005^{* * *} \\
(-3,60)\end{array}$ & $\begin{array}{c}-0,005^{* * *} \\
(-3,67)\end{array}$ & $\begin{array}{c}-0,005^{* * *} \\
(-3,62)\end{array}$ & $\begin{array}{c}-0,005^{* * *} \\
(-3,63)\end{array}$ \\
\hline SqC.CRED & & & & $\begin{array}{c}-0,0004 \\
(-0,69)\end{array}$ \\
\hline SqP.CRED & & & & $\begin{array}{c}0,0005 \\
(0,33)\end{array}$ \\
\hline No. of Obs. & 415 & 415 & 415 & 415 \\
\hline No. of instrument & 21 & 21 & 21 & 21 \\
\hline$A R(1)$ & 0,000 & 0,000 & 0,000 & 0,000 \\
\hline$A R(2)$ & 0,780 & 0,842 & 0,832 & 0,835 \\
\hline Hansen test & 0,305 & 0,287 & 0,256 & 0,255 \\
\hline
\end{tabular}

Note: numbers in bracket $($.$\left.) indicate t-statistics, and asterisk marks with \left({ }^{*}\right),{ }^{* *}\right)$ and $\left(^{* * *}\right)$ indicate the estimated coefficients are statistically significant at level of $10 \%, 5 \%$ and $1 \%$ respectively. 
inequality-widening effect, at least over period 2002-2016. We also find that institutional quality is a key factor for reducing income inequality in any situation as coefficients on PCI are negative in all regressions. In addition, there is a little obvious evidence that the presence of FDI sector helps to deplete income inequality. This could be true given that FDI companies in Vietnam mostly focus on taking advantage of cheap and low-skilled labor, which results in lowering income gap between low skilled laborers and high-skilled ones.

As for testing the existence of an inverted U-shaped relationship between credit and income inequality, we in turn add squared term of C.CRED and P.CRED into the model and adopt the same regression techniques. The results show that none of coefficients of this variable is statistically significant. Therefore, the analysis does not provide adequate evidence to support the hypothesis of Greenwood and Jovanovic (1990). However, the inverted U-shaped hypothesis may still hold in the case of Vietnam. The justification is that Vietnam is now at early stage of its development path and maybe it has not yet reached the critical point that after this point inequality would tend to reduce.

\section{Conclusion and Policy Implications}

On dissecting a panel data of 60 provinces/cities in Vietnam over the period 2002-2016, this paper finds empirical evidence proving the impact of credit on income inequality. The empirical results half-support the non-linear hypothesis that expanding credit market in the country would lead to higher level of inequality. The results also confirm the important role of policy credit and education in fighting against inequality in Vietnam.

The credit market is essential to drive economic growth, and inequality during the booming era of credit market is inevitable in Vietnam. It is due to the fact that a majority of the population lives in rural areas, while the banking system is mainly based in urban areas, and a large proportion of the labor force is low-skilled and has got less income and properties, which lower the chance those people could pursue economic opportunities posed by credit market expansion. Therefore, and in the current circumstances of Vietnam, it could be possible to draw some policy implications from the above findings. Firstly, government should direct flows of credit to real economic activities rather than speculative investment. Secondly, more bank credit should be allocated to rural areas and agriculture. Thirdly, government should also seek to design favorable credit programs that promote education of the overall population, especially of those living in rural areas, in poor economic condition areas, and belonging to the ethnic minority. These policy implications will be more thoroughly implemented when the government performs its comprehensive financial development strategy.
The Philippines, Brazil, Mexico and China are countries that have achieved significant success in implementing the comprehensive financial development strategy. Vietnam can learn from the experience of these countries to develop its own appropriate national strategy.

\section{References}

Aghion, P., \& Bolton, P. (1997). A theory of trick-down growth and development. Review of Economic Studies, 64(2), 151-172

Ang, J. (2010). Finance and inequality: The case of India. Southern Economic Journal, 76(3), 738-761

Asad, H. (2012), Effective Financial Development, Inequality and Poverty (PhD Thesis). University of Exeter, Exeter, England.

Asian Development Bank (2015). Key Indicators for Asia and the Pacific 2015.

Baligh, N., \& Pirace, K. (2013). Financial development and income inequality relationship in Iran. Middle-East Journal of Scientific Research, 13(S), 56-64.

Banerjee, A., \& Newman, A.F. (1993). Occupational choice and the process of development. Journal of Political Economy, 101(2), 274-98.

Batuo, M.E., Guidi, F., \& Mlambo, K. (2010). Financial Development and Income Inequality: Evidence from African Countries (MPRA Paper No. 25658).

Beck, T., Demirgũc-Kunt, A., \& Levine, R. (2007). Finance, inequality and the poor. Journal of Economics Growth, 12, 27-49.

Bittencourt, M.F.M. (2010). Financial Development and Inequality: Brazil 1985-99 (Discussion Paper No. 06/582). University of Bristol, Bristol, England.

Clarke, G., Xu, L.C., \& Zou, H. (2003). Finance and Income Inequality: Test of Alternative Theories (World Bank Policy Research Working Paper No.2984).

Cornia, G.A., \& Court, J. (2001). Inequality, growth and poverty in the era of liberalization and globalization (UNU-WIDER No.4). Helsinki, Finland: United Nations University.

Cruz, J.F., \& Imperial, F.A. (2014). The finance-inequality linkage: The effect of financial development to income distribution in the Philippines. Paper presented at the 52nd Annual Meeting of the Philippine Economic Society, Hotel Intercontinental Manila, Makati City.

Dhrifi, A. (2013). Financial development and the growth-inequalitypoverty triangle: A comparative study between developed and developing countries. International Journal of Economics, Finance and Management, 2(7), 472-481.

Galor, O., \& Zeira, J. (1993). Income distribution and macroeconomics. Review of Economic Studies, 60, 35-52.

Greenwood, J., \& Jovanovic, B. (1990). Financial development, growth, and the distribution of income. Journal of Political Economy, 98, 1076-1107. 
Ha, V.D. (2019). The interactive relationship between credit growth and operational self-sustainability of People's Credit Funds in Mekong Delta Region of Vietnam. Journal of Asian Finance, Economics and Business, 6(3), 55-65. https://doi.org/10.13106/ jafeb.2019.vol6.no3.55

Honohan, J. (2007). Cross-country variation in household access to financial services. Paper presented at the Conference Access to Finance, Washington DC.

Jalil, A., \& Feridun, M. (2011). Long-run relationship between income inequality and financial development in China. Journal of the Asia Pacific Economy, 16(2), 202-214.

Kappel, V. (2010). The Effects of Financial Development on Income Inequality and Poverty (Working Paper 10/127). CER-ETH Center of Economic Research at ETH Zurich.

Law, S. H., \& Tan, H.B. (2009). The role of financial development on income inequality in Malaysia. Journal of Economic Development, 34(2), 153-168.

Law, S. H., Tan, H.B., \& Azman-Saini, W.N.W. (2014). Financial Development and Income Inequality at Different Levels of Institutional Quality. Emerging Markets Finance \& Trade, 50(1), 21-33.

Le, Q. H., \& Chu, M.H. (2012). Financial Development and Income Inequality in Việt Nam: An Empirical Analysis. Journal of Economics and Development, 14(2), 5-25.

Le, Q. H., \& Chu, M.H. (2013). Financial sector development and income inequality in Vietnam: Evidence at the provincial leve. Journal of Southeast Asian Economies, 30(3), 263-77.

Liang, Z. (2006). Financial development and income distribution: A system GMM panel analysis with application to urban China. Journal of Economic Development, 31(2), 1-21.
Mago, S. (2014). Microfinance and poverty alleviation: An empirical reflection. Journal of Asian Finance, Economics and Business, 1(2), 5-13. https://doi.org/10.13106/jafeb.2014.vol1.no2.5.

Nguyen, C., Bigman, D., Berg, M.V., \& Vu, T. (2007). Impact of Microcredit on Poverty and Inequality: The Case of the Vietnam Bank for Social Policies. Retrieved from https://mpra.ub.uni-muenchen. de/54154/1/MPRA_paper_54154.pdf, dated 20/2/2012.

Nguyen, H.H., \& Lien, T.T. (2019). Factors influencing family business decision for borrowing credit from commercial banks: Evidence in Tra Vinh province, Viet Nam. Journal of Asian Finance, Economics and Business, 6(2), 119-122. https://doi. org/10.13106/jafeb.2019.vol6.no2.119

Pham, T.H., \& Riedel, J. (2019). Impacts of the sectoral composition of growth on poverty reduction in Vietnam. Journal of Economics and Development, 21(2), 85-96.

Ohno, K. (2010). Avoiding the middle-income trap: Renovating industrial policy formulation in Vietnam. Vietnam Development Forum (VDF), Hanoi.

Roodman, D. (2006). How to Do xtabond2: An introduction to "Difference" and "System" GMM in Stata (Working Paper 103). Washington, D.C.: Center for Global Development.

Shahbaz, M., \& Islam, F. (2011). Financial development and income inequality in Pakistan: An application of ARDL approach. Journal of Economic Development, 36(1), 35-58.

GSO. (2019). General Statistics in 2018. Hanoi, Vietnam: Statistic Publishing House.

Zhang, Q., \& Cheng, R. (2015). Financial development and income inequality in China: An application of SVAR approach. Procedia Computer Science, 55, 774-781. 